\title{
ASSOCIATION OF FUNCTIONAL OUTCOME AND POST STROKE DEPRESSION AMONG ISCHEMIC STROKE PATIENTS AFTER THREE MONTHS ONSET: A PRELIMINARY STUDY
} \author{
Hastaning Sakti4 ${ }^{4}$ J.B. Suparyatma5, Mateus Sakundarno Adi6 \\ 1. Doctoral Programm, Medicine Faculty, Diponegoro University \\ 2. Professor in Nursing Faculty, Indonesia University \\ 3. Neurologist, Medicine Faculty, Diponegoro University \\ 4. Psychology Faculty, Diponegoro University \\ 5. Patologist, Medicine Faculty, Sebelas Maret University \\ 6. Epidemiologist, Public Health Faculty, Diponegoro University
}

Fitria Handayani1, Setyowati², Dwi Pudjonarko3 ${ }^{3}$ Dian Ratna Sawitri ${ }^{4}$,

\begin{abstract}
The Post Stroke Depression (PSD) prevalence among stroke patients after three months onset was high. Functional Outcome influenced depression on stroke patient. This study aimed to investigate the correlation between these variables. This study was a correlational study. The participants were 44 ischemic stroke patients after three months onset, recruited in an outpatient unit. The tools were GRIDHamilton Rating Scale for Depression 17 (GRID-HAMD 17) for PSD and Barthel Index (BI) for functional outcome. Data was examined using simple linier regression analyses. The prevalence of PSD was 56.82. The median of HAMD-GRID-17 was $10.38 \pm 7.58$, and Barthel Index was $69.56 \pm 21.69$. The Barthel Index showed a positive correlation with HAMD-GRID-17 ( $\beta=-.41 \rho=.006)$. The Functional Outcome influences PSD as many as $16.8 \%$. Correlation between Functional Outcome and PSD in ischemic stroke patients demonstrated a moderate association. Nursing intervention development that consists of functional outcome repairmen to reduce PSD among ischemic stroke patients should be aimed.
\end{abstract}

Keywords: Functional Outcome, Post Stroke Depression, After Three Months Onset

\section{ABSTRAK}

Prevalensi Post Stroke Depression pada pasien stroke setelah tiga bulan tinggi.. Functional Outcome mempengaruhi depresi pada pasien stroke iskemik.. Penelitian ini bertujuan untuk mengetahui korelasi kedua variable. Partisipan yang terlibat adalah 44 pasien stroke setelah tiga bulan serangan. Pasien adalah pasien unit rawat jalan. Kuesioner adalah GRID-Hamilton Rating Scale for Depression 17 (GRID-HAMD 17) untuk PSD dan Barthel Index (BI) untuk functional outcome. Data dianalisis menggunakan regresi linier sederhana. Presentasi PSD adalah 56.82. HAMD-GRID-17 adalah $10.38 \pm$ 7.58 dan Barthel Index adalah $69.56 \pm 21.69$. Barthel Index dan HAMD-GRID-17 menunjukan hubungan yang positip $(\beta=-.41 \rho=.006)$. Functional Outcome menentukan PSD sebesar16.8 \%. Hubungan antara Functional Outcome dan PSD pada pasien stroke iskemik setelah tiga bulan serangan adalah sedang. Intervensi keperawatan yang berfokus pada status fungsional untuk menurunkan PSD harus dikembangkan.

Kata kunci: Functional Outcome, Post Stroke Depression, Tiga Bulan Setelah Serangan 


\section{BACKGROUND}

Depression is a common phenomenon which follows a stroke incident. Among ischemic stroke patients, pattern of Post Stroke Depression (PSD) score was increased within three months after onset and persistent until six month (Gbiri, Akinpelu, \& Odole, 2010). The score at three month was highest among period after stroke onset. At three months after onset, patient engaged with real life in dealing with stroke (Gbiri, Akinpelu, \& Odole, 2010). The prevalence of PSD three months after onset was vary, $31.6 \%$ were in risk of PSD (McCarthy et al., 2016), 27.3\% (Li et al., 2014) and 33.5\% had major PSD (Cheng et al., 2014), and 47.4\% experienced PSD (Kim et al., 2011). Besides a high range, PSD also causes fatigue after one and a half year after the onset (Lerdal et al., 2011), prolonged PSD and suicidal thought ( $E$. Lang \& Borgwardt, 2013), low of quality of life after five years onset (Kielbergerova et al., 2015), and recurrent stroke (Yuan et al., 2012). In-addition stroke patient with PSD has 4.4 times of mortality risk than non-PSD stroke patient (Naess, Lunde, Brogger, \& Waje-Andreassen, 2010). Functional Outcome is another common complication of stroke. Functional Outcome after stroke rates of $49 \%$ (Khan et al., 2012) and $60.9 \%$ (Ojagbemi \& Owolabi, 2013) have been reported. A higher score of functional outcome is associated with the Return Home Program versus institution-based rehabilitation (Stein et al., 2015).

Stroke patient with functional outcome impairment has mortality risk of 1.7 (Naess et al., 2010). It was found that there was a significance difference of functional outcome between PSD and non-PSD in stroke patient (X.-G. Jiang, $\mathrm{Lin}, \& \mathrm{Li}, 2014)$. Although the association of functional outcome and PSD has been well established among stroke patient, the association of functional outcome and PSD among stroke patient after three months onset has not been well described. The determination to opt three months after the initial stroke was because the pattern of PSD score mostly increases at three months after onset (Gbiri, Akinpelu,
\& Odole, 2010), this study was aimed to investigate the association of functional outcome and PSD among stroke ischemic survivor after three months onset. The association between PSD and executive function as considered treatment factor at three months after onset.

\section{METHODS}

\section{a. Sample}

Screening to 120 stroke patients was performed since February to May 2018. Forty four patients who were suffering from ischemic stroke after three months of onset were eligible for this study based on the inclusion and exclusion criteria. The sampling method was convenience sampling during the study period. Samples were recruited at outpatient service in Tugurejo Hospital and Kanjeng Raden Mas Tumenggung Wongsonegoro (KRMT) Hospital, Semarang City, Indonesia. The participants had experienced an acute ischemic stroke onset which was diagnosed according to the AHA 2013. Stroke is classically characterized by a neurological deficit attributed to an acute focal injury of the central nervous system (CNS) by a vascular cause, including cerebral infarction, intra cerebral hemorrhage $(\mathrm{ICH})$, and subarachnoid hemorrhage $(\mathrm{SAH})$, and becomes a major cause of disability and death worldwide (Sacco et al., 2013). The criteria of inclusion including, 18- 80 years old, admitted to the hospital within three months after stroke onset, had no aphasia and MMSE score $>12$. The exclusion criteria was patient with hearing impairment. The drop out was hemorrhage transformation. Ethic was legally from and. Ethical approval was obtained from the Ethics and Research Committee of Medicine Faculty, Diponegoro University in affiliation with Kariadi Hospital. Considering the hospital research procedure, Ethical approval was rechecked at Tugurejo Hospital. The participants received an explanation regarding research procedure and were then given an informed consent. 
b. Assessment

Assessment of PSD used GRID-HAMD 17. The questionnaire consists of 17 questions (Williams et al., 2008). The GRID-HAMD 17 has passed language validity. Backward translation was conducted into Bahasa and continued with face validity. Reliability test of GRIDHAMD 17 among stroke patient was also conducted with Alpha Cronbach, $r=.766$. Assessment of executive function was conducted using Barthel-Index (Mahoney \& Barthel, 1965)(Oveisgharan et al., 2006). The tool was tested with inter-ratter observation between two observers. The Kappa result was .001.
C. Statistics Analysis

Participants' clinical and sociodemographic characters such as age, sex, income, and education were presented using descriptive statistics frequencies. Characteristics of age and GRID-HAMD 17 data continuum were analyzed for homogeneity using Saphiro-Wilk. Homogeneity of variance was determined using median or mean. Age and GRIDHAMD 17 presented in mean/median and standard deviation. Post Stroke Depression and Executive Functional category also described in percentages. Post Stroke Depression and Executive Functional continuum data were analyzed in simple linier regression. Level of significance was set at $\rho<.05$.

\section{RESULTS}

Table 1 Characteristics of Participants

\begin{tabular}{|c|c|c|c|c|}
\hline Characteristics & n (participants) & $\%$ & Median (Range) & IQR \\
\hline \multicolumn{5}{|l|}{ Sex } \\
\hline - Male & 20 & 45.5 & & \\
\hline Female & 24 & 54.5 & & \\
\hline \multicolumn{5}{|l|}{ Employed } \\
\hline - Employed & 18 & 40.9 & & \\
\hline - Unemployed & 26 & 41.9 & & \\
\hline \multicolumn{5}{|l|}{ Education } \\
\hline - Low Education & 40 & 90.9 & & \\
\hline $\begin{array}{l}\text { - Higher } \\
\quad \text { Education }\end{array}$ & 4 & 9.1 & & \\
\hline \multicolumn{5}{|l|}{ Income } \\
\hline - Low & 23 & 52.3 & & \\
\hline - Moderate & 20 & 45.5 & & \\
\hline - High & 1 & 2.3 & & \\
\hline Age & & & 57.9 (38-78) years & \pm 8.87 \\
\hline
\end{tabular}

The continuum data of GRIDHAMD 17 and $\mathrm{BI}$ were not normally distributed. The median of GRID-HAMD 17 was $10.38 \pm 7.58(0-26)$, and $\mathrm{BI} 69.56$ $\pm 21.69 \quad(20-85)$ respectively. The percentages of PSD of ischemic stroke patients after 3 month onset were $43.2 \%$ no depression, $40.9 \%$ mild, $4.5 \%$ moderate, and $11.4 \%$ severe. The percentages of Functional Outcome were $70.5 \%$ mild dependent, $13.6 \%$ moderate dependent, $11.4 \%$ dependent, and $4.5 \%$ total dependent.

Table 2 Univariate of Post Stroke Depression and Functional Outcome

\begin{tabular}{|c|c|c|c|c|}
\hline & $\mathbf{n}$ & $\%$ & Median (Range) & IQR \\
\hline GRID-HAMD 17 & & & $10.38(0-26)$ & \pm 7.58 \\
\hline$\leq 7$ no depression & 19 & 43.2 & & \\
\hline$\leq 18$ Mild & 18 & 40.9 & & \\
\hline$\leq 24$ Moderate & 2 & 4.5 & & \\
\hline$>24$ Severe & 5 & 11.4 & & \\
\hline Barthel Index & & & $69.56(20-85)$ & \pm 21.69 \\
\hline Total Dependent & 2 & 4.5 & & \\
\hline
\end{tabular}




\begin{tabular}{lllll}
\hline & $\mathbf{n}$ & $\%$ & Median (Range) & IQR \\
\hline Dependent & 5 & 11.4 & & \\
Moderate & 6 & 13.6 & & \\
Mild & 31 & 70.5 & & \\
Independent & 0 & 0 &
\end{tabular}

Table 3 Simple linier Regression

\begin{tabular}{lllll}
\hline Factor & $\mathbf{C}$ & $\begin{array}{l}\text { Unstandardized } \\
\text { Coefficient } \\
\mathbf{B}\end{array}$ & $\begin{array}{l}\text { Standardized } \\
\text { Coefficient } \\
(\boldsymbol{\beta})\end{array}$ & $\boldsymbol{\rho}$ \\
\hline Functional Outcome & 20.25 & -.142 & -.41 & $<.001$ \\
\hline $\mathrm{R} 2=.168$, adjusted R2 $=.148$, & & &
\end{tabular}

The correlation between Functional outcome and PSD among ischemic stroke patients after three month onset showed moderate and negative pattern at -.41. A higher Functional Outcome decreases PSD. Coefficient determination was .168. The coefficient demonstrated that linier regression determined $16.8 \%$ variation of functional outcome well explain to the PSD variable. Statistical analysis showed a significance correlation between Functional Outcome and PSD among ischemic stroke patients after three months onset $p=<.001$.

\section{DISCUSSION}

This study examined the association between functional outcome and PSD among ischemic stroke patient after three months onset. Our study showed that the percentage of PSD among ischemic stroke patients after three month onset was higher than that in other studies (McCarthy et al., 2016)(Li et al., 2014)(Cheng et al., 2014)(Kim et al., 2011). In this study, the percentage of functional outcome impairment was 100\% ranged from mild to totally dependent, meanwhile other studies found the impairment were $49 \%$ (Khan et al., 2012) and $60.9 \%$ (Ojagbemi \& Owolabi, 2013). The results of our study showed negative moderate association between functional outcome and PSD. Other studies supported that PSD at discharge and after three months onset was associated with functional outcome, although PSD does not influence the motor recovery (Nannetti, Paci, Pasquini, Lombardi, \& Taiti, 2005). Depression at three month after onset correlated with poor functional outcome at 15 months after onset (Kaste, Erkinjuntti,
Pohjasvaara, Vataja, \& Leppa, 2001). Major depression was strongly associated with functional dependency (Ojagbemi \& Owolabi, 2013).

In comparison of statistics analysis, many studies showed that functional outcome using $\mathrm{Bl}$ score was significantly difference between PSD and non PSD group in stroke patient after three months onset (Nannetti et al., 2005)(X.-G. Jiang et al., 2014). Specifically in ischemic stroke patient after three months onset, the $\mathrm{Bl}$ score was also different (Tang et al., 2013). However, few studies found there was no significance difference of $\mathrm{BI}$ between PSD and nonPSD in ischemic stroke after three months onset (Zhang et al., 2010). In multivariate statistics analysis, it was stated that handicap (mRS score) predicted the occurrence of PSD among ischemic stroke patient at three months onset (Zhang et al., 2010).

For unspecified time after stroke, comparison analysis supported that post stroke disability using mRS score was significantly different among stroke patient (Oni, Olagunju, Olisah, Aina, \& Ojini, 2018). Functional score was included into multivariate model in predicting the PSD among ischemic stroke patient with other variables (Tang et al., 2013).

Correlation of PSD and functional outcome can be explained by lesion area. The cortex area lesion which determined PSD and Functional Outcome Post Stroke Depression showed higher rates of infarcts in cortical-subcortical area of the frontal and temporal lobe as well as in internal capsule (including genu, anterior and posterior limb) (Zhang et al., 2012)(X. Jiang, Lin, \& Li, 2014). 
Other studies, however, found a different result. One study asserted that Functional Outcome and depression is not correlated (Lohner, Brookes, Hollocks, Morris, \& Markus, 2017). Physical disability and psychiatric rating scale, which measure the emotional dimension of disability caused by the disease expresses as depression, showed no correlation as well. The PSD is not a simple reaction to physical disability (Bendsen, Bendsen, Lauritzen, \& Vilmar, 1997). Other influencing factors toward PSD and its pattern need to be investigated among ischemic stroke patient after three months onset.

It is widely agreed that The Functional Outcome and PSD should be treated. One of studies suggested that physical exercise improves physical functional recovery after stroke (Pyöriä et al., 2007). The incident of Post Stroke Depression can also be diminished after patients receiving a treatment. The treatment was psychosocial intervention. The indicator of PSD was 5-HTTLPR and STin2 VNTR polymorphisms of the SERT genotyped in DNA (Kohen et al., 2011).

\section{CONCLUSION}

The Functional Outcome was moderately correlated with Post Stroke Depression on ischemic stroke patient after three months onset. Nursing intervention development which consisted of functional outcome enhancement in order to reduce PSD among ischemic stroke patients after three months onset should be aimed. The obvious limitation is this study explained only one variable which influences PSD in stroke ischemic patient after three months onset, therefore other variables need to be examined in addressing the PSD phenomena.

\section{ACKNOWLEDGMENT}

This research was funded by the annual grant of the Indonesian Ministry of Research, Technology and Higher Education.

\section{REFERENCES}

Bendsen, B. B., Bendsen, E. B., Lauritzen, L., \& Vilmar, T. (1997). Post-stroke patients in rehabilitation: The relationship between biological impairment (CT scanning ), physical disability and clinical depression. European Psychiatry: The Journal of the Association of European Psychiatrists, 12, 399-404

Cheng, S., Zhao, Y., Li, J., Chen, X., Wang, R., \& Zeng, J. (2014). Plasma levels of glutamate during stroke is associated with development of post-stroke depression. Psychoneuroendocrinology, 47(183), 126-135.

Gbiri, C. A., Akinpelu, A. O., \& Odole, A. C. (2010). Prevalence, pattern and impact of depression on quality of life of stroke patients. International Journal of Psychiatry in Clinical Practice, 14(March), 198-203.

Jiang, X. G., Lin, Y., \& Li, Y. S. (2014). Correlative study on risk factors of depression among acute stroke patients. European Review for Medical and Pharmacological Sciences, 18(9), 1315-1323.

Kaste, M., Erkinjuntti, T., Pohjasvaara, T., Vataja, R., \& Leppa, A. (2001). Depression is an independent predictor of poor long-term functional outcome post-stroke. European Journal of Neurology, 8(4), 315-319.

Khan, M., Ahmed, B., Ahmed, M., Najeeb, M., Raza, E., Khan, F., ... Kamal, A. K. (2012). Functional, cognitive and psychological outcomes, and recurrent vascular events in Pakistani stroke patients: a cross sectional study. BMC Research Notes, 5(1), 89.

Kielbergerova, L., Mayer, O. J., Vanak, J., Bruthans, J., Wohlfahrt, P., \& Ciffkova, R. (2015). Quality of life predictors in chronic stable poststroke patients and prognostic value of SF-36 score as a mortality surrogate. Translational Stroke Research, 6(5), 375-383. 
Kim, J. T., Park, M. S., Yoon, G. J., Jung, H. J., Choi, K. H., Nam, T. S., ... Cho, K. H. (2011). White matter hyperintensity as a factor associated with delayed mood disorders in patients with acute ischemic stroke. European Neurology, 66(6), 343349.

Kohen, R., Cain, K. C., Buzaitis, A., Johnson, V., Becker, K. J., Teri, L., ... Mitchell, P. H. (2011). Response to psychosocial treatment in poststroke depression is associated with serotonin transporter polymorphisms. Stroke, 42(7), 20682070.

Lang, U. E., \& Borgwardt, S. (2013). Molecular Mechanisms of Depression: Perspectives on New Treatment Strategies. Cellular Physiology and Biochemistry, 31, 761-777.

Lerdal, A., Bakken, L. N., Rasmussen, E. F., Beiermann, C., Ryen, S., Pynten, S., ... Kim, H. S. (2011). Physical impairment, depressive symptoms and pre-stroke fatigue are related to fatigue in the acute phase after stroke. Disability and Rehabilitation, 33(4), 334-342.

Li, J., Zhao, Y., Zeng, J., Chen, X., Wang, R., \& Cheng, S. (2014). Serum Brain-derived neurotrophic factor levels in post-stroke depression. Journal of Affective Disorders, 168, 373-379.

Lohner, V., Brookes, R. L., Hollocks, M. J., Morris, R. G., \& Markus, H. S. (2017). Apathy, but not depression, is associated with executive dysfunction in cerebral small vessel disease. PLOS ONE, 12(5), e0176943.

Mahoney, F. I., \& Barthel, D. W. (1965). Functional evaluation: The Barthel Index. Maryland State Medical Journal, 14(Feb), 61-65.
McCarthy, M. J., Sucharew, H. J., Alwell, K., Moomaw, C. J., Woo, D., Flaherty, M. L., ... Kissela, B. M. (2016). Age, subjective stress, and depression after ischemic stroke. Journal of Behavioral Medicine, 39(1), 55-64.

Naess, H., Lunde, L., Brogger, J., \& WajeAndreassen, U. (2010). Depression predicts unfavourable functional outcome and higher mortality in stroke patients: The Bergen Stroke Study. Acta Neurologica Scandinavica, 122(SUPPL. 190), 34-38.

Nannetti, L., Paci, M., Pasquini, J., Lombardi, B., \& Taiti, P. G. (2005). Motor and functional recovery in patients with post-stroke depression. Disability and Rehabilitation, 27(4), 170-175.

Ojagbemi, A., \& Owolabi, M. (2013). Predictors of functional dependency after stroke in Nigeria. Journal of Stroke and Cerebrovascular Diseases, 22(8), e381-e387.

Oni, O. D., Olagunju, A. T., Olisah, V. O., Aina, O. F., \& Ojini, F. I. (2018). Post-stroke depression: Prevalence, associated factors and impact on quality of life among outpatients in a Nigerian hospital. The South African Journal of Psychiatry: The Journal of the Society of Psychiatrists of South Africa, 24, 1058.

Oveisgharan, S., Shirani, S., Ghorbani, A., Soltanzade, A., Baghaei, A., Hosseini, S., \& Sarrafzadegan, N. (2006). Barthel Index in a MiddleEast Country: Translation, validity and reliability. Cerebrovascular Diseases, 22, 350-354.

Pyöriä, O., Talvitie, U., Nyrkkö, H., Kautiainen, H., Pohjolainen, T., \& Kasper, V. (2007). The effect of two physiotherapy approaches on physical and cognitive functions and independent coping at home in 
stroke rehabilitation: A preliminary follow-up study. Disability and Rehabilitation, 29(6), 503-511.

Sacco, R. L., Kasner, S. E., Broderick, J. P., Caplan, L. R., Connors, J. J., Culebras, A., ... Vinters, H. V. (2013). An updated definition of stroke for the 21st century: A statement for healthcare professionals from the American heart association/American stroke association. Stroke, 44(7), 20642089.

Stein, J., Bettger, J. P., Sicklick, A., Hedeman, R., Magdon-Ismail, Z., \& Schwamm, L. H. (2015). Use of a standardized assessment to predict rehabilitation care after acute stroke. Archives of Physical Medicine and Rehabilitation, 96(2), 210-217.

Tang, W. K., Liang, H., Chu, W. C. W., Mok, V., Ungvari, G. S., \& Wong, K. S. (2013). Association between high serum total bilirubin and post-stroke depression. Psychiatry and Clinical Neurosciences, 67(4), 259-264.

Williams, J. B. W., Kobak, K. A., Bech, P., Engelhardt, N., Evans, K., Lipsitz, J., ... Pearson, J. (2008). The GRIDHAMD: standardization of the Hamilton Depression Rating Scale. International Clinical Psychopharmacology, 23(3), 120129.

Yuan, H. W., Wang, C. X., Zhang, N., Bai, Y., Shi, Y. Z., Zhou, Y., ... Wang, Y. J. (2012). Poststroke depression and risk of recurrent stroke at 1 year in a Chinese cohort study. PLOS ONE, 7(10).

Zhang, T., Jing, X., Zhao, X., Wang, C., Liu, Z., Zhou, Y., ... Wang, Y. (2012). A prospective cohort study of lesion location and its relation to post-stroke depression among Chinese patients. Journal of Affective Disorders, 136(1-2), e83-7.
Zhang, T., Wang, C., Liu, L., Zhao, X., Xue, J., Zhou, Y., ... Wang, Y. (2010). A prospective cohort study of the incidence and determinants of post-stroke depression among the mainland Chinese patients. Neurological Research, 32(4), 347352. 